\title{
Reform and Development of Vocational Education in Fujian Province from the Collaborative Innovation Perspective
}

\author{
Xinbing Sun \\ Scientific Research Department \\ Minjiang University \\ Fuzhou, China 350108
}

\begin{abstract}
The vocational education in Fujian Province faces the chances coexisting with challenges under the new normal of economy. This paper summarizes the good achievements attained by the vocational education of Fujian Province in the aspects such as school scale, talent training level, overall development of various kinds of vocational education and the ability of serving local economic development in the new century; analyzes the problems of weak targeted vocational education in Fujian Province in its development process in the aspects such as insufficient attraction, low motivation in school-enterprise cooperation and weak basic ability; proposes to develop the vocational education of Fujian Province relying on the construction innovation of Free Trade Zone, and to learn the advanced experience of Taiwan vocational education to vigorously development vocational education, improve talent cultivation mode, practically improve the professional skills and accomplishment of students of vocational education college, establish the pragmatic and long-term school-enterprise cooperation mechanism and promote the positive development of industry-university-research cooperation.
\end{abstract}

Keywords—new normal; vocational education; reform

\section{INTRODUCTION}

Currently, China's economy has developed into the new normal, with the development of manufacturing industries facing new challenges. Facing the new situation and welcoming new challenges, China has formulated the plan of China Made 2025 which is known as "China Industry 4.0". The prosperity of manufacturing industry is inseparable from the progress of vocational education. Fujian Province has obtained good achievements through active development of vocational education and striving to promote manufacturing industry development. However, it also faces some difficulties, and it can be said changes coexisting with challenges.

\section{ACHIEVEMENTS OBTAINED BY VOCATIONAL EDUCATION OF FUJIAN PROVINCE IN NEW CENTURY}

\section{A. Constantly Expand the School Scale of Vocational} Education, Gradually Improve Talent Cultivation Level

In 2016, a total of 916,000 students received vocational education in Fujian Province, among whom, 37,000 students in technical school, 559,000 students in secondary vocational school, and 320,000 students in higher vocational school. Students enrolled in vocational education in Fujian Province have increased from 786,000 in 2006 to 916,000 in 2016. Particularly, with the development of applied-orientation undergraduate education in recent years, the school scale of vocational education in Fujian Province is significantly expanded, the level of running is enhanced gradually, which have provided more high-level applied-orientation technical talents and promoted the economic and social development of Fujian Province effectively.

The talent cultivation level of vocational education in Fujian Province is gradually enhanced while the school level is constantly expanded. In 2006, the number of students receiving higher vocational education, secondary vocational education and technical education in Fujian Province has undergone great change, and the students of these three types have enhanced from 27:62:11 in 2006 to 35:61:4 in 2016. As for the students receiving higher vocational education, the quantity has been improved to 320,000 from 215,000 with the growing rate of $148.9 \%$, the proportion structure also rises by 8 percent, and the talent cultivation level is gradually improved All the data in "Table I" indicate that, the vocational education in Fujian Province is enhanced in terms of both "quantity" and "quality" in the new era, realizing the sound and rapid development.

CLC Number: G644 Document Code: A.

Fund Project: Education Research Project of Young Teachers in Fujain Province in 2016 (JAS160420); Special Project of Cross-strait Vocational Education Exchange and Cooperation of Fujian Provincial Department of Education, Project of Fujian Branch of National Institute of Vocational Education (GZM15005) 
UNIT: TEN THOUSAND PEOPLE, \%

\begin{tabular}{|c|c|c|c|c|c|c|c|}
\hline \multirow{2}{*}{ Year } & \multirow{2}{*}{$\begin{array}{c}\text { Total Number of Students in Higher } \\
\text { Vocational, Secondary Vocational and } \\
\text { Technical Schools } \\
\end{array}$} & \multicolumn{2}{|c|}{ Higher Vocational School } & \multicolumn{2}{|c|}{ Secondary Vocational School } & \multicolumn{2}{|c|}{ Technical School } \\
\hline & & $\begin{array}{c}\text { Number of } \\
\text { students }\end{array}$ & Proportion & $\begin{array}{c}\text { Number of } \\
\text { students }\end{array}$ & Proportion & $\begin{array}{c}\text { Number of } \\
\text { students }\end{array}$ & Proportion \\
\hline 2006 & 78.6 & 21.5 & 27 & 48.6 & 62 & 8.5 & 11 \\
\hline 2007 & 81.2 & 23.2 & 29 & 49.4 & 61 & 8.6 & 10 \\
\hline 2008 & 84.1 & 25.3 & 30 & 49.8 & 59 & 8.9 & 11 \\
\hline 2009 & 85.5 & 25.7 & 30 & 51.3 & 60 & 8.5 & 10 \\
\hline 2010 & 86.7 & 26 & 30 & 51.2 & 59 & 9.5 & 11 \\
\hline 2011 & 88.3 & 27.4 & 31 & 52.1 & 59 & 8.8 & 10 \\
\hline 2012 & 88.9 & 27.6 & 31 & 54.2 & 61 & 7.1 & 8 \\
\hline 2013 & 89.6 & 28.7 & 32 & 54.7 & 61 & 6.3 & 7 \\
\hline 2014 & 90.5 & 29.9 & 33 & 55.2 & 61 & 5.4 & 6 \\
\hline 2015 & 91.2 & 31 & 34 & 55.6 & 61 & 4.6 & 5 \\
\hline 2016 & 91.6 & 32 & 35 & 55.9 & 61 & 3.7 & 4 \\
\hline
\end{tabular}

B. The Role of Market Mechanism Has Been Given to Full Play, and Various Kinds of Vocational Education Is Developed in An Overall Manner

In recent years, the reform and development of vocational education in Fujian Province has received high attention from the provincial Party committee and provincial government, as they make efforts to establish modern vocational education system and issue a series of policies to support the reform and development of vocational education, which have mobilized the role of market effectively and promoted the overall development of various kinds of vocational education. In 2016, there were a total of 41 higher vocational education schools in Fujian province, with 226,800 students receiving private higher vocational education, among them there were 151,500 undergraduates, 65,300 junior college students, accounting for $30.1 \%$ and $28.6 \%$ respectively of the undergraduates and junior college students in the whole province. There were 36 private secondary vocational schools in Fujian Province with 31,800 students, accounting for $20.3 \%$ and $6.8 \%$ respectively of that of the whole province as in "Table II".

TABle II. The Development of Various Kinds of Private Education at All LeVels in Fujian Province IN 2016 Unit: School, Ten Thousand PEOPLE, \%

\begin{tabular}{|c|c|c|c|c|c|c|c|c|c|c|}
\hline & \multicolumn{4}{|c|}{$\begin{array}{c}\text { Number of Private Higher Educational } \\
\text { Institutions }\end{array}$} & \multicolumn{4}{|c|}{$\begin{array}{c}\text { Number of Students in Private Higher } \\
\text { Educational Institutions }\end{array}$} & \multirow{2}{*}{$\begin{array}{c}\text { Number of } \\
\text { Private } \\
\text { Secondary } \\
\text { Vocational } \\
\text { Schools }\end{array}$} & \multirow[b]{2}{*}{$\begin{array}{l}\text { Number of Students } \\
\text { in Private } \\
\text { Secondary } \\
\text { Vocational School }\end{array}$} \\
\hline & Total & $\begin{array}{c}\text { Undergra } \\
\text { duate } \\
\text { college }\end{array}$ & $\begin{array}{c}\text { Indepen } \\
\text { dent } \\
\text { college }\end{array}$ & $\begin{array}{l}\text { Junior } \\
\text { college }\end{array}$ & Total & $\begin{array}{l}\text { Undergr } \\
\text { aduate } \\
\text { college }\end{array}$ & $\begin{array}{c}\text { Independent } \\
\text { college } \\
\text { (undergradua } \\
\text { te) }\end{array}$ & $\begin{array}{l}\text { Junior } \\
\text { college }\end{array}$ & & \\
\hline \multirow{2}{*}{ Quantity } & \multirow{2}{*}{41} & \multirow{2}{*}{5} & \multirow{2}{*}{12} & \multirow{2}{*}{24} & \multirow{2}{*}{22.68} & 3.86 & 11.29 & \multirow{2}{*}{6.53} & \multirow{2}{*}{36} & \multirow{2}{*}{3.18} \\
\hline & & & & & & 15.15 & & & & \\
\hline $\begin{array}{l}\text { Proportion of } \\
\text { whole province }\end{array}$ & 39.6 & 16 & 100 & 35.1 & 28.3 & 30.1 & & 28.6 & 20.3 & 6.8 \\
\hline
\end{tabular}

In recent years, the quality of workforce has been improved comprehensively and the worker skill training is strengthened in Fujian Province, which has promoted the development of various kinds of non-degree education. In 2016, the number of students registered in vocational and technical training institutions of various kinds of non-degree education in Fujian Province reached 817,900 with the graduates of 808,100 ; the students registered in secondary vocational education reached 163,100 with the graduates of 196,800 as in "Table III".

Table III. Situation of Students of the Non-degree Education at All LeVels in Fujian Province in 2016 Unit: Ten Thousand People

\begin{tabular}{|l|l|l|}
\hline \multicolumn{1}{|c|}{ Item } & Number of Graduates (Course-Completion Students) & Number of Registered Students \\
\hline Vocational and technical training institution & 80.81 & 81.79 \\
\hline Qualification training & 4.36 & 3.21 \\
\hline Job certificate training & 26.69 & 23.98 \\
\hline Secondary vocational education & 19.68 & 16.31 \\
\hline Qualification training & 11.32 & 9.62 \\
\hline Job certificate training & 4.98 & 3.95 \\
\hline
\end{tabular}

C. The Ability to Serve Local Economy Has Been Enhanced, and the Disciplines and Professional Layouts Have Been Continuously Optimized

In recent years, the vocational education in Fujian Province takes initiatives to adjust discipline professional layout, increase the adjustment intensity according to the economic and social development demands, making the relationship between vocational education and economic and social development closer. The newly built undergraduate colleges adjust the specialty distribution and establish discipline specialty group to serve the local economic and social 
development centering on application-oriented personnel training requirements and adhering on the school-running status as in "Table IV".

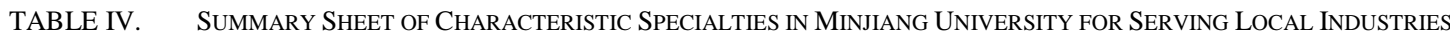

\begin{tabular}{|c|c|c|c|}
\hline No. & Name of Major & Major Orientation & Service Orientation \\
\hline 1 & Electrical engineering and automation & $\begin{array}{l}\text { Power, electronics and new energy technology, industrial } \\
\text { automation applications }\end{array}$ & $\begin{array}{l}\text { High-end machinery and equipment industry } \\
\text { New energy technology }\end{array}$ \\
\hline 2 & Textile engineering & Textile design & $\begin{array}{l}\text { Traditional characteristic industries } \\
\text { (Textile industry) }\end{array}$ \\
\hline 3 & $\begin{array}{l}\text { Mechanical and electronic } \\
\text { engineering }\end{array}$ & $\begin{array}{l}\text { Intelligent manufacturing } \\
\text { Equipment technology }\end{array}$ & High-end machinery and equipment industry \\
\hline 4 & Polymer materials and engineering & None & $\begin{array}{l}\text { Traditional characteristic industry- } \\
\text { Functional fiber material }\end{array}$ \\
\hline 5 & Advertising & New media communication & Advertising (new media communication) \\
\hline 6 & E-commerce & E-commerce & Modern service industry (E-commerce) \\
\hline 7 & Tourism management & $\begin{array}{l}\text { International travel agency management } \\
\text { international tourism marketing direction, exhibition, } \\
\text { tourism management direction }\end{array}$ & Modern service industry - tourism \\
\hline
\end{tabular}

\section{PROBLEMS EXIST IN CURRENT REFORM AND \\ DEVELOPMENT OF VOCATIONAL EDUCATION IN FUJIAN PROVINCE}

\section{A. Weak Targeted College Vocational Education}

At present, there exists the "dilemma" phenomenon in the society, as many enterprises have insufficient high quality employees, while a large number of graduates cannot find a suitable job. With the transformation and upgrading of economic structure, such "dilemma" phenomenon will become serious. Many college students only grasp the theoretical knowledge and are lack of the vocational skills matching the market demands. The students cultivated by colleges cannot adapt to the economic and social development, and the quality and structure of talent cultivation is disconnected with the market demand [1]. Generally speaking, it is the result of weak targeted vocational training of colleges.

\section{B. The Attraction to Society by Vocational Education Especially the Secondary Vocational Education Is Still Insufficient}

In 2013, the people's government of Fujian Province issued Some Opinions on Supporting Reform and Development of Higher Vocational Colleges, developed vocational education vigorously, proposed to build the "interchange" for talent cultivation by vocational education. Moreover, there are reports from social media that "the season the most difficult to find a job in history is coming", students from higher vocational and secondary vocational school become the "favorite" and other correct direction of public opinion. However, the attraction of vocational education especially the secondary vocational schools and technical schools is still falling, and it is hard to reverse within a short time.

\section{Enterprises Have no High Enthusiasm for School- enterprise Cooperation}

The majority of current school-enterprise cooperation is the cooperation sought by the school with enterprises for survival, and few enterprises seek cooperation with schools actively. Since 2010, Fujian Province issued a series of policies for vocational educational reform and education, encouraging schools to establish extensive connection with enterprises, and build the practice base jointly. Generally speaking, however, the promotion of school-enterprise cooperation is still not ideal, and the contradiction of school-enterprise cooperation is still prominent, leading to the disconnection of students' employment ability and enterprise demand directly.

\section{Basic Ability of Vocational Education Is Still Weak}

The uneven development of various vocational schools in Fujian Province is still prominent, as there are both the statelevel model vocational institutions and substandard vocational schools; there is large difference from region to region, with the vocational education in the mountain area of North Fujian is relatively lagged behind. As for the faculty, full time teachers in vocational schools are insufficient, and the professional competence of teaching needs to be improved.

\section{SUGGESTIONS FOR THE REFORM AND DEVELOPMENT OF VOCATIONAL EDUCATION IN FUJIAN PROVINCE}

\section{A. Develop the Vocational Education in Fujian Province in an Innovative Way Relying on the Free Trade Zone Construction}

In 2014, the State Council determined to set up China (Fujian) Pilot Free Trade Zone. The free trade zone takes "open to Taiwan" and "full cooperation" as its orientation, carries out the investment access policy, cargo trade facilitation measures, expanding the opening of service industry and other aspect first, and takes the lead in realizing liberalization of cargo and service trade in the zone. Various kinds of vocational colleges in Fujian Province shall give full play to the advantage of free trade zone, take the talent demand in free trade zone as breakthrough, reform vigorously, develop school-enterprise cooperation in depth centering on the industry structure of free trade zone and enterprise ecology, give full play to the advantages of enterprises in the aspects such as specialty design, formulation of cultivation program, course design and the certification of professional qualifications, so as to reach the deep integration of school and enterprise. "Sharing-type vocational education construction is the most realistic choice for economy development." As a 
result, to solve the problem of educational resource shortage in Fujian Province, it is necessary to break traditional concept and use the innovative mechanism. Opening vocational education college in free trade zone directly can introduce teachers from free trade zone directly, moreover, it can also facilitate students to participate in practical training, broaden international vision and update management concept. Constructing vocational education college in free trade zone can help to centralize the use of funds, improve the utilization rate of vocational education resource, to achieve effective integration of vocational education resources [2].

\section{B. Learn the Advanced Experience of Vocational Education from Taiwan to Develop Fujian's Vocational Education Vigorously}

Since the 1960s, Taiwan authorities encourage running school through multiple channels actively and develop private vocational education vigorously in order to accelerate the cultivation of professional and technical talents that society badly needs. Government is unable to take full responsibility for the investment in vocational education due to limited resource of government, so it is need to take advantage of the investment from society and enterprise. Fujian Province is the hometown of overseas Chinese with many foreign enterprises. So we can give full play to the advantage of overseas Chinese and foreign enterprises, formulate preferential policies, to attract overseas Chinese and foreign enterprises to jointly invest in the vocational education. In addition, the incentive and security mechanisms for enterprises and individuals to participate in vocational education shall be established and improved. Strengthen the policy supporting of private vocational colleges, guide and encourage social fund investment and develop vocational education, support private colleges strongly in terms of fund support, construction land and revenue according to the principle of "active encourage, strong support, correct guidance and legal management" as specified by the Private Education Promotion Law. To promote the sound development of private vocational education, it is necessary to strengthen the guidance and management of private vocational colleges [3].

\section{Improve Talent Cultivation Mode, Effectively Improve the Professional Skills and Accomplishments of the Students of Higher Vocational Colleges}

In the current transitional period of higher education, Fujian Province shall actively support the transformation of provincial undergraduate college to applied-orientation colleges, strengthen the construction of applied-orientation characteristic undergraduate colleges, select part of the colleges or specialties as a pilot, integrate industry demand and social need, highlight vocational education characteristics, cultivate talents that are in urgent need by the enterprise, and provide effective carrier for the construction of modern vocational education system [4]. At present, various provincial undergraduate colleges in Fujian Province are actively carrying out the experimental construction of applied-orientation colleges to strengthen the construction of applied-orientation characteristic elite schools, so as to promote the development of higher vocational education in Fujian Province through the construction of applied-orientation colleges. After several years of pilot work, the students cultivated can truly adapt to the demands by industries and enterprises, and become the talents integrating practice and academy closely. To achieve the cultivation of vocational education talents at different levels, the close integration of curriculum system among corresponding secondary vocational education, higher vocational education, and applied-orientation undergraduate colleges shall be established. Establish the vocational colleges integrating secondary vocational education, higher vocational education and applied-orientation undergraduate colleges, so as to facilitate the completion of talent cultivation mode of "staged cultivation and through-type learning" within one college and the systematic cultivation of senior skilled personnel.

\section{Establish the Practical and Long-term School-enterprise Mechanism and Promote the Sound Development of Industry-university-research Cooperation}

One important point of modern vocational education system construction is to strengthen and deepen schoolenterprise cooperation, expand the cooperation scale, deepen the cooperation content, to enable the school-enterprise cooperation to obtain practical results. Various vocational colleges in Fujian Province shall review themselves in full first of all, learn about their own situation, take initiative to perform teaching reform, improve the target and quality of talent cultivation and strengthen the ability of serving local economic social development taking their own advantages against local industry characteristics and the need of talents for enterprise transformation [5]. Fujian provincial government shall actively guide the enterprises to participate in the education and teaching of vocational colleges, take initiative to formulate the encouraging and incentive policy for school-enterprise cooperation, strengthen the investment of talent cultivation fund, and build a number of industry-university-research integration bases dominated by the government with joint participation of vocational colleges and enterprises; encourage the enterprises and vocational colleges to jointly formulate talent cultivation program and set the specialties according to the actual needs of enterprise, encourage enterprise personnel to participate in the daily teaching in vocational colleges actively, so as to improve students' practical operation ability; encourage enterprises to set research center in the vocational colleges, strengthen collaborative innovation and promote integration development.

\section{CONCLUSION}

Under the background of economic new normal, the transformation and upgrading of economy has increased high requirements for the technological content of the product and the sophistication of production process, which has brought great challenge to the employees' skill level and knowledge structure. Only by performing profound reform, can the vocational education adapt to the demand of economic new normal for talents. Fujian Province will develop vocational education in an innovative way relying on free trade zone; learn the advanced experience from Taiwan vocational education to develop vocational education vigorous; improve 
talent cultivation mode, effectively improve the professional skill and accomplishments of students of vocational education colleges; establish practical and long-term school-enterprise cooperative mechanism, and promote the sound development of industry-university-research cooperation.

\section{REFERENCES}

[1] Lu Jie. Education Dictionary (Vol. 1) [Z]. Shanghai: Shanghai Educational Publishing House. 1990.147.

[2] Zhang Zhenyuan. Exploration on Several Problems of Skill Classification [J]. Vocational and Technical Education, 2007, (28).

[3] Li Xiaoping. New Basic Psychology [M]. Nanjing: Nanjing Normal University Press, 2005.110.

[4] Wu Zunmin. Research on Improving Modern National Education System and Constructing Lifelong Education System [J]. Journal of Chinese Society of Education, 2004, (4).

[5] Zeng Guoping. Carry Forward the Tradition of Natural Dialectics. Build the Science and Technology Group [J]. Journal of Beijing University of Chemical Technology (Social sciences edition), 2002, (3). 